\title{
African organisational coaching practice: exploring approaches used, and the factors influencing coaches' fees
}

Article

Published Version

Creative Commons: Attribution 4.0 (CC-BY)

Open Access

Terblanche, N. ORCID: https://orcid.org/0000-0002-67966008, Passmore, J. ORCID: https://orcid.org/0000-0003-08327510 and Myburgh, J. ORCID: https://orcid.org/0000-00018574-556X (2021) African organisational coaching practice: exploring approaches used, and the factors influencing coaches' fees. South African Journal of Business Management, 52 (1). ISSN 2078-5585 doi: https://doi.org/10.4102/sajbm.v52i1.2395 Available at https://centaur.reading.ac.uk/98893/

It is advisable to refer to the publisher's version if you intend to cite from the work. See Guidance on citing.

Published version at: http://dx.doi.org/10.4102/sajbm.v52i1.2395

To link to this article DOI: http://dx.doi.org/10.4102/sajbm.v52i1.2395

Publisher: AOSIS Publishing

All outputs in CentAUR are protected by Intellectual Property Rights law, including copyright law. Copyright and IPR is retained by the creators or other copyright holders. Terms and conditions for use of this material are defined in the End User Agreement. 


\section{www.reading.ac.uk/centaur}

\section{CentAUR}

Central Archive at the University of Reading

Reading's research outputs online 


\section{African organisational coaching practice: Exploring approaches used, and the factors influencing coaches' fees}

\begin{abstract}
Authors:
Nicky Terblanche ${ }^{1}$ (D)

Jonathan Passmore ${ }^{2}$

Jacques Myburgh ${ }^{3} \mathbb{0}$

Affiliations:

${ }^{1}$ University of Stellenbosch

Business School, Faculty of Economic and Management

Science, Stellenbosch

University, Cape Town,

South Africa

${ }^{2}$ Henley Business School Faculty of Economic and Management Science, University of Reading, Henley-on-Thames, United
\end{abstract} Kingdom

${ }^{3}$ SA Coaching News, Cape Town, South Africa

Corresponding author:

Nicky Terblanche,

nicky@flipside.co.za

Dates:

Received: 05 Oct. 2020

Accepted: 14 Feb. 2021

Published: 14 Apr. 2021

How to cite this article: Terblanche, N., Passmore, J. \& Myburgh, J. (2021). African organisational coaching practice: Exploring approaches used, and the factors influencing coaches' fees. South African Journal of Business Management, 52(1), a2395. https://doi.org/10.4102/ sajbm.v52i1.2395

\section{Copyright:}

(C) 2021. The Authors. Licensee: AOSIS. This work is licensed under the Creative Commons Attribution License.
Purpose: More context-specific research regarding the praxis of organisational coaching was needed for increased understanding of this emerging profession. Whilst progress was being made internationally, African coaching practice research was sparse, leading to potentially false assumptions about local praxis based on international trends. The aim of this research was to gain a context-specific perspective on the coaching approaches used by organisational coaches in Africa and the factors that influence the rates they charge.

Design/methodology/approach: Snowball sampling was used to collect survey data from organisational coaches practicing in Africa $(n=299)$. Data were analysed using descriptive and inferential statistics.

Findings/results: Organisational coaches in Africa predominantly use the Behavioural or Goal-focussed or GROW approach, but employ more sophisticated approaches in more complex situations. They charge a mean rate of R1761 (\$1041) per hour (R1573 [\$93] in South Africa) with higher qualified, more experienced and older coaches charging a higher rate. Receiving supervision plays no role in rates charged; however, belonging to a coaching body correlates to higher rates. Male and female coaches charge similar rates, suggesting a level of gender equality in the African coaching profession.

Practical implications: Organisational coaches should ensure they have a wide repertoire of approaches to cater for the complexity of organisational situations. Coaches could increase their rates by obtaining high quality coaching education and join coaching regulatory bodies. Coaches in Africa could expand their market internationally given that they charge significantly lower rates, especially given the acceptance of virtual coaching in recent times.

Originality/value: This is the first study to our knowledge that investigates pan-African coaching praxis.

Keywords: organisational coaching; executive coaching; African coaching; coaches in Africa; coaching practice; coaching rates; coaching fees; coaching approaches.

\section{Introduction}

Coaching is often described in literature as a multi-billion dollar per year industry and an emerging profession that has shown significant growth globally over the last few years (Athanasopoulou \& Dopson, 2018; Bozer \& Jones, 2018). Several meta-studies have shown that coaching is effective and provides several positive outcomes, including, for example, leadership development (Kombarakaran, Yang, Baker \& Fernandes, 2008); personal development and positive behavioural change (Athanasopoulou \& Dopson, 2018); improved work-life balance, self-awareness, assertiveness and role clarity (Blackman, Moscardo \& Gray, 2016).

Continued academic research is important if coaching is to establish itself as a true profession. Numerous studies have focussed on coaching efficacy, but in comparison, research on coaching praxis is relatively sparse (Theeboom, Beersma \& Van Vianen, 2014), prompting a recent shift in coaching research direction. New questions are now being investigated, such as: What influences the success of a coaching intervention? What actually happens in a coaching session? Which approaches, models, tools and techniques work best in which scenarios? and How does one create and operate a viable coaching business? (De Haan, Bertie, Day \& Sills, 2010; Terblanche, Jock \& Ungerer, 2019). However, almost all of this recent research has been conducted outside of the African coaching context. 
In line with the current coaching practice research trend and given the paucity of coaching research in an African context, this study asked two questions relating to organisational coaching practice: (1) Which coaching approaches do African coaches use in various presenting situations; and (2) Which factors influence the rates African coaches charge for their coaching services?

An understanding of the application of context-specific coaching approaches and the funding thereof may help practicing coaches, coach trainers and purchasers of coaching services to value and opt for coaching interventions appropriately tailored for an African context, instead of merely copying what is practiced in other parts of the world. In fact, knowledge of how much organisations are currently paying for coaching in Africa may also help to demonstrate the perceived value of coaching. Furthermore, insight into the rates and factors influencing rates charged by organisational coaches in Africa may create a more realistic picture of the viability of creating and maintaining a coaching practice in this context. Comparing these rates with international benchmarks may also suggest opportunities for African coaches to competitively expand their practices internationally.

\section{Literature review}

\section{Background to organisational coaching}

As a testimony to its emerging status, organisational coaching currently has a variety of definitions. An amalgamation of definitions suggests that coaching is beneficial as an individual and organisational learning and development intervention (Grant, Cavanagh \& Parker, 2010; Maltbia, Marsick \& Ghosh, 2014); and that it is a structured process employing various tools and strategies to achieve a positive outcome for multiple stakeholders (Bachkirova, Cox \& Clutterbuck, 2014; Passmore \& Fillery-Travis, 2011). The focus of the present study was on coaching within organisations, which comprises various genres including executive, management, leadership and business coaching (Grant, 2012; Stern, 2004).

Coaching is a growing practice. In 2019, there were an estimated 71000 coaches worldwide (International Coach Federation [ICF], 2020a), up from approximately 47500 in 2011 (Dunlop, 2017). In South Africa, there are approximately 1700 coaches currently registered with the Coaches and Mentors of South Africa (COMENSA) (J. Myburgh, personal communication, 01 October 2020). The ICF reported 488 coaches in South Africa and 511 in the rest of Africa as on August 2020 (ICF, 2020b).

Blackman et al. (2016) argued that coaching has always been around in organisations, but that it has changed over the years from initial practitioners (1950-1979) informally working with executives using organisational and psychological techniques, to the present where the growing profession is backed by an increasing number of research publications, professional bodies and formal qualifications.
Coaching in its current form probably originated in North America in the 1980s before spreading to Europe (Passmore \& Lai, 2019). Coaching only arrived much later (towards the end of the 1990s) in South Africa and the rest of Africa (StoutRostron, 2006). Given its roots in the Global North and the temporal lag of its arrival in Africa, coaching practice in Africa is less researched and therefore less well understood. This raises a number of questions including: Which coaching approaches are actually used in Africa? How do they compare with the rest of the world?

\section{Coaching approaches}

Coaching borrows from many fields, including management, education, social sciences, philosophy, psychology and adult learning (Cox, Bachkirova \& Clutterbuck, 2014). This eclectic basis leads to numerous applications of coaching, as summarised by Cox et al. (2014). This rich and diverse offering seems positive at first glance, because it implies that many different contexts are covered; however, little research is available on which approaches are actually used and how effective they are in different scenarios. In their meta-analysis, Athanasopoulou and Dopson (2018) found that the type of coaching is mentioned in less than half of the coaching studies examined. Of the reported approaches in their analysis, cognitive behavioural was the most popular, followed by the solution-focussed and positive psychology or strengths coaching approaches. Their meta-study related to coaching research, but what about coaching practice? In a 2017, European-wide (45 countries) coaching practice survey $(n=2791), 23 \%$ of coaches reported using a Behavioural or GROW approach, $16 \%$ solution-focussed approach and $11 \%$ each neuro-linguistic programming (NLP) and cognitive behavioural approaches (Passmore, Brown, Csigas et al., 2017).

The recent Sherpa Coaching survey made a crude differentiation between coaching practices by distinguishing between 'strengths-' and 'weakness'-based coaching (Sherpa Coaching, 2020). Strengths-based coaching is modelled on positive psychology, whereas weakness-based coaching suggests that a client needs to overcome their limitations in order to progress. The Sherpa Coaching survey found that weakness-based coaching is more likely to be favoured by internal coaches and that these coaches model their coaching approach on published coaching approaches. In contrast, strengths-based coaches develop their own coaching approach.

In a South African study $(n=148), 63 \%$ of participants indicated that they used their own coaching model, $59 \%$ used a positive psychology approach and $40 \%$ of coaches used a narrative approach (participants were allowed to select more than one option) (Schutte, 2019). No research could be found on Pan-African coaching approaches, an aspect addressed in the present study.

\section{Running a coaching business}

The second aspect of coaching praxis addressed in the present study is that of rates charged by organisational coaches in 
Africa. Many people are drawn to the profession of coaching as an alternative career (ed. Passmore, 2015). However, the reality is that many coaches struggle to make a living from coaching. Terblanche et al. (2019) found that one of the main challenges is over-optimism about earnings potential.

In terms of rates charged, one study $(n=400)$ revealed that $25 \%$ of coaches (all types) surveyed in the United Kingdom had earned less than $£ 5000$ from coaching per year since 2009 (Cavett, 2015). Organisational coaches seem to fare better. In a study in the United States of America $(n=428)$, the average hourly coaching rate was $\$ 237$ (Bono, Purvanova, Towler \& Peterson, 2009), whilst the top-end coaches charged up to $\$ 3500$ per hour (Couto \& Kauffmann, 2009). In a PanEuropean study, 37\% of coaches charged $€ 200$ or higher per hour, $22 \%$ charged $€ 100$ or less per hour and $10 \%$ charged $€ 400$ or higher per hour (Angulo, Passmore \& Brown, 2019).

The Sherpa Coaching Survey (2020) found that so-called weakness-based coaches charged more per hour than strengths-based coaches, with $69 \%$ of weakness-based coaches charging $\$ 500$ or more compared with $63 \%$ of strenghts-based coaches. Their survey also found that more experienced coaches earn more. Coaching with 10-15 years' experience earns \$122 000 per annum whilst coaches with more than 15 years' experience earn $\$ 160000$ per annum at an hourly rate of over $\$ 450$ on average. A recent ICF survey found that the global average earning for coaches was $\$ 47100$ with the Middle East and African (treated as one region in the survey) coaches earning significantly less at \$34 900 per annum (ICF, 2020a).

The only African study ( $n=148)$ that was found, revealed that South African coaches charge between R550 (\$321) and R1850 (\$110) per hour with an average of R1034 (\$60) per hour (Schutte, 2019); however, it is not clear whether these rates were exclusive to organisational coaching. To the best of our knowledge, no study has enquired about organisational rates across Africa and importantly, none of the studies attempted to determine which factors influence the rates charged. These important questions are addressed in the present study.

\section{Methodology \\ Research design}

This research followed a quantitative design using a crosssectional survey as data collection instrument. Data were analysed using descriptive and inferential statistics.

\section{Survey instrument and sample}

The survey used for a Pan-European research study (Passmore et al., 2017) was used with slight modification for the African context. The original survey asked questions about coaches' experience, their coach training and details about their coaching practice, coaches' fee rates for individual and organisational coaching (per hour), how they rated themselves compared with colleagues, and the extent they used supervision, self-reflection and forms of personal development (Passmore \& Dromantaite, 2020). Modifications for the African context included reference to South African currency (for rates charged), African coaching bodies and different coaching focus areas. The survey was pre-tested with a sample of local African coaches to ensure clarity and logical flow. The survey was made available on the Internet and tooks approximately 20 min to complete.

\section{Data collection}

A link to the survey was distributed to coaches working in Africa through the researchers' personal networks and relevant coaching bodies including COMENSA, the ICF and the Africa Executive Coaching Council (AECC). In total 349 valid responses were received from 19 countries. A subsample of the data collected $(n=299)$, which excluded non-organisational coaches was used as the results shared in this article focus on coaching approaches used and factors that influence the rates coaches charge in an organisational context.

\section{Data analysis}

For descriptive purposes, frequencies and percentages were reported. Relationships between corporate rates and ordinal variables (e.g. age) were investigated using Pearson correlation analyses. Mean rates between males and females, as well as coaching body members versus non-members were compared using one-way analysis of variance (ANOVA).

\section{Ethical considerations}

Participants were informed of the confidential and anonymous nature of the study where they provided consent before starting the survey. Ethical clearance was obtained from the Research Ethics Committee of the Henley Business School at the University of Reading.

\section{Results Demographics}

Of the 299 organisational coaches, approximately 32\% $(n=95)$ self-identified as male and $68 \%(n=204)$ as female. Those belonging to a coaching body represented approximately $84 \%(n=252)$ of the sample whilst $16 \%$ $(n=47)$ did not belong to a coaching body. In terms of location, approximately $74 \%(n=222)$ of coaches were from South Africa and 26\% $(n=77)$ from the rest of Africa.

\section{Coaching approaches used}

Coaches were asked about the coaching approaches they were trained in and which approaches they predominantly used. They were able to select multiple options. The results reveal that African coaches are trained and use a variety of approaches, but some approaches are more popular than 


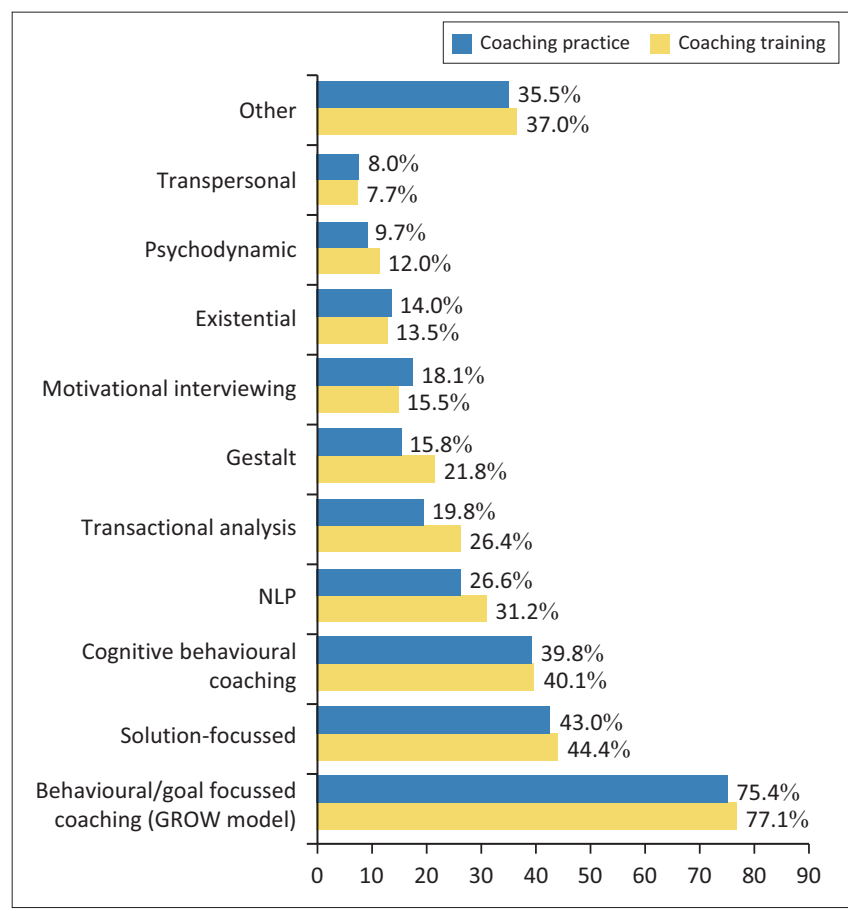

NLP, neuro-linguistic programming; GROW, Goal, [current] Reality, Options [or obstacles], Will [or way forward].

FIGURE 1: Coaching approaches trained and used by organisational coaches in Africa.

others (see Figure 1). The most common coaching approach trained $(77.1 \%)$ and used $(75.4 \%)$ is Behavioural or Goal-focussed coaching using the GROW model. Solutionfocussed is second (trained $44.4 \%$; used $43 \%$ ), followed by Cognitive Behavioural (trained 40.1\%; used 39.8\%). Other approaches are used significantly less frequently: NLP $(26.6 \%)$, transactional analysis $(19.8 \%)$, motivational interviewing (18.1\%), Gestalt $(15.8 \%)$, existential $(14 \%)$, Psychodynamic $(9.7 \%)$ and transpersonal $(8 \%)$. In all cases, there is a fairly close alignment between the approaches coaches were trained in, and how often they use those approaches.

Coaches were also asked to indicate which coaching approach they use in different presenting situations. When faced with career coaching scenarios (Figure 2), coaches opted for the arguably less-complex Behavioural or GROW (52.4\%) approach.

However, when faced with the more challenging scenario of diversity issues (Figure 3), coaches employed more sophisticated approaches, like Cognitive Behavioural (18.3\%), more so than the Behavioural or GROW (14.3\%) approach. Other more complex approaches, such as Transpersonal (8.4\%), Existential (7.2\%) and Gestalt (6.3\%) are also used significantly more than in the career coaching scenario.

These findings can be seen in the context of the Sherpa Coaching survey finding that $31 \%$ of coaches following a proposed process, compared with $29 \%$ who used their own developed process. However, the majority (39\%) adapted their coaching approach based on the unique needs of each

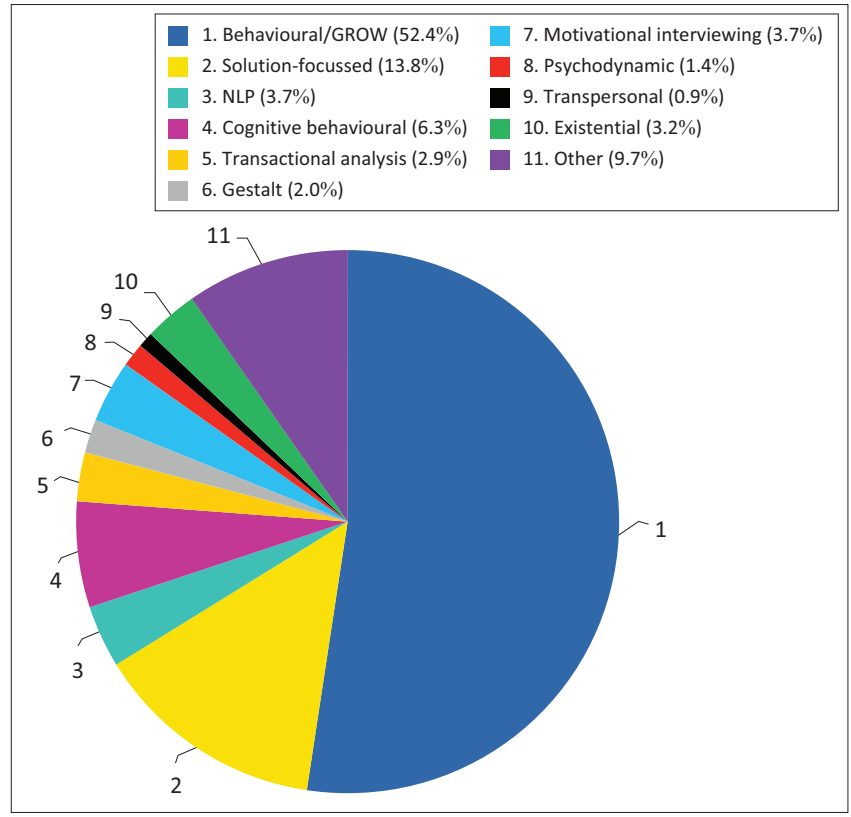

NLP, neuro-linguistic programming; GROW, Goal, [current] Reality, Options [or obstacles], Will [or way forward].

FIGURE 2: Coaching approaches used during career transition scenarios.

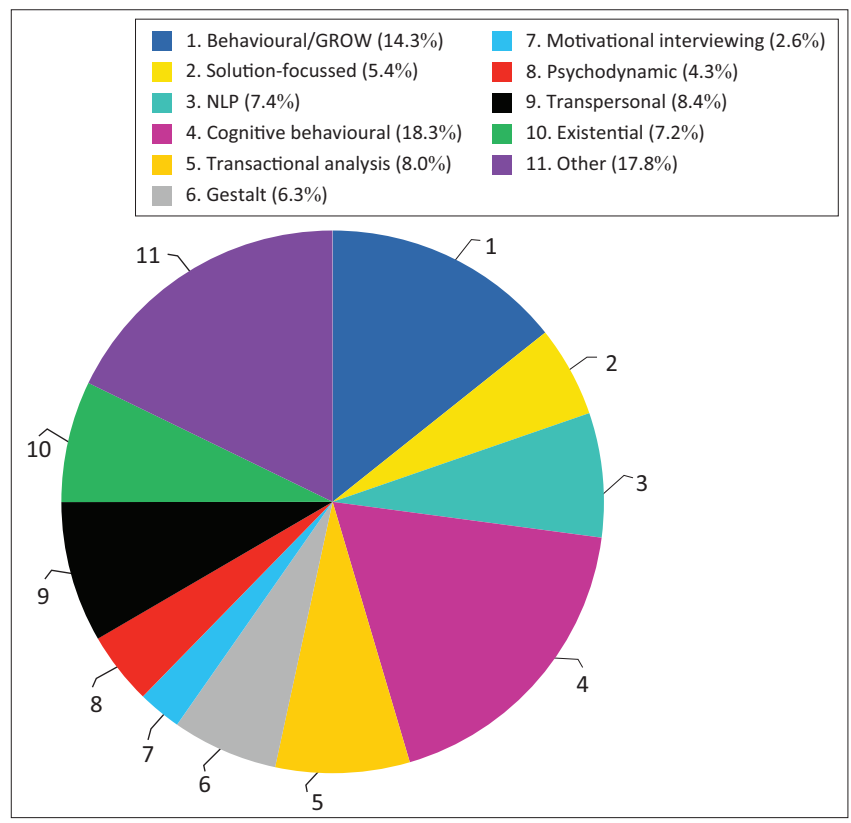

NLP, neuro-linguistic programming; GROW, Goal, [current] Reality, Options [or obstacles], Will [or way forward].

FIGURE 3: Coaching approaches used during diversity issue scenarios.

client (Sherpa Coaching, 2020). Following this global trend, the finding of the present study suggests that coaches in Africa also adapt their approach based on the specific client's need.

\section{Coaching rates charged}

The correlations (Table 1) between the corporate rate charged by coaches across Africa and their age, coaching qualification, coaching experience and whether or not they received coaching supervision are shown. Values for South Africa only are shown in brackets. 
TABLE 1: Pearson's correlations for corporate coaching rate.

\begin{tabular}{lccccc}
\hline Variable & \multicolumn{2}{c}{ Pearson } & & \multicolumn{2}{c}{$p$} \\
\cline { 2 - 3 } \cline { 5 - 6 } & Africa & South Africa & & Africa & South Africa \\
\hline Age & 0.17 & 0.27 & & $<0.01$ & $<0.01$ \\
Qualification & 0.29 & 0.39 & & $<0.01$ & $<0.01$ \\
Experience & 0.28 & 0.35 & & $<0.01$ & $<0.01$ \\
Supervision & 0.06 & 0.10 & & 0.31 & 0.13 \\
\hline
\end{tabular}

The age, qualification and experience (Table 1) are statistically significantly $(p<0.01)$ correlated to corporate coaching rate charged. For all of Africa, age has a small positive correlation (Pearson coefficient $=0.17$ ), whereas qualification (Pearson coefficient $=0.29$ ) and experience (Pearson coefficient $=0.28$ ) have medium positive correlations to corporate rates charged. For South Africa only, these correlations are more significant (Age: 0.27; Qualification: 0.39; Experience: 0.35). There is no correlation between supervision received and corporate coaching rate in Africa $(p=0.31)$ or South Africa $(p=0.13)$.

The ANOVA results show that, in terms of actual rates, there was no statistically significant $(p=0.48)$ difference between how much men and women charge. The overall mean rate is R1761 (\$104) per hour for all of Africa and R1573 (\$93) per hour for South Africa. There was however a significant $(p<0.03)$ difference between the rates charged by coaches who belong to a coaching body: R1827 (\$107) and those who do not: R1404 (\$83).

\section{Discussion}

This research set out to investigate organisational coaching praxis in Africa and specifically the coaching approaches used by coaches, the rates charged and factors that influence these rates.

\section{Coaching approaches used}

African coaches are exposed to a relatively narrow selection of coaching approaches during their training, the predominant one being the Behavioural or Goal-focussed or GROW approach. This approach, especially the GROW model, is considered a foundational approach to coaching, widely used by novice coaches (Stout-Rostron \& Van Rensburg, 2009, p. 66). More complex approaches, such as Gestalt, Existential and Psychodynamic, are generally used less frequently. This potentially points to coaches in Africa using less-sophisticated approaches when compared with, for example, coaches in Europe where only 23\% reported to use the Behavioural or Goal-focussed or GROW (Passmore et al., 2017). Our result also differs from a South African study (Schutte, 2019) that found South African coaches to predominantly use their own coaching model and a positive psychology approach.

Although African coaches rely mostly on the Behavioural or Goal-focussed or GROW approach, they demonstrate a level of flexibility in particular scenarios. When presented with an arguably more complex scenario of diversity issues, coaches in Africa are able to reduce their reliance on the Behavioural or Goal-focussed or GROW approach and engage with more complex coaching approaches, such as Transpersonal, Existential and Gestalt. This points to an awareness that one size does not fit all and is also a possible indication of the maturing nature of coaching praxis in Africa.

\section{Coaching rates charged}

The results indicate that higher age, experience and level of coaching qualification are linked to higher coaching rates charged. This result does not come as a surprise per se, but does perhaps help to refute a stigma attached to coaching. In the past, coaching was regarded as a 'wild west' (Sherman \& Freas, 2004) where anyone could call themselves a coach. Whilst coaching remains an unregulated industry and some of the assertions of Sherman and Freas are still true in essence, the results from the present study indicate that at least in Africa, experience and the level of coaching training are rewarded by the buyers of coaching services through a higher rate paid. This is indeed an encouraging result and points to the maturing of coaching as a profession.

It is interesting to note that being in supervision did not correlate to a higher rate charged. Some scholars believe that supervision is a crucial part of coaching becoming a recognised profession (Hawkins, Turner \& Passmore, 2019). One would therefore expect that more experienced coaches would be in supervision and that they would be charging a higher rate. Anecdotal evidence, however, suggests that there is resistance to supervision from some coaches, especially in South Africa. The result from the present study confirms that supervision is not yet considered important in Africa by experienced, wellqualified coaches and indicates that coaching may still have a way to go before it can consider itself a profession as per Hawkins et al. (2019).

An encouraging sign in terms of gender equality is that there is no difference between the rates charged by men and women, which is in contrast to the findings of the recent Sherpa Coaching Survey (2020). In their survey, at the top end of the scale, $18 \%$ of women earn $\$ 500$ or more compared with $21 \%$ of men. At the bottom end of the scale, $45 \%$ of women earn less than $\$ 300$ compared with $36 \%$ or men.

Finally, the average hourly rate of R1761 (\$104) charged by organisational coaches in Africa is significantly less than in Europe and the United States of America. In Europe, 37\% of coaches charge $€ 200$ or higher (Passmore et al., 2017) and in the United States of America in 2009 already, the average rate was \$237 (Bono et al., 2009). The global Sherpa Coaching Survey (2020) found that even new coaches with less than two years experience charge on average $\$ 300$ per hour. This significant price difference between coaches in Africa and global coaches presents an opportunity. Coaches 
in Africa could possibly expand their offering into the global market, given their price advantage and that virtual coaching is becoming more accepted, especially as a result of the Covid-19 pandemic.

\section{Limitations and recommendations}

A potential limitation of this study is the relatively smaller representation in the sample of non-South African coaches compared with coaches from the rest of Africa. The ICF membership numbers state that there are more members in the rest of Africa than in South Africa, suggesting that the sample is not as representative as it could be. The results used in this article were, however, based on statistical significance trends. In terms of coaching approaches used it would have been revealing to understand to what extent coaches with a formal background in psychology use psychologically based coaching approaches such as existential, gestalt and psychodynamics versus coaches not schooled in psychology who may opt for non-psychological approaches such as GROW. This is a suggestion for future research.

This study makes a number of recommendations. As coaches seem to use more complex coaching approaches in more complex scenarios, organisational coaches should ensure they have a wide repertoire of approaches to cater for the complexity of organisational situations in the African context. Coaches should thus re-engage with continuous learning and development. Coaching training institutions in Africa should also take note and ensure that they offer training in coaching approaches beyond the basics.

Coaches who want to increase their rates are encouraged to obtain a high-quality coaching qualification and join coaching regulation bodies. Procurers of coaching services could use the level of qualification, experience and age of the coach to guide how much to pay coaches. The average hourly organisational coaching rate of R1761 (\$104) could be used as a guideline by both coaches and purchasers to assign a value to coaching services. This rate charged by coaches in Africa is significantly lower than what coaches charge in Europe and the United States of America. Coaches in Africa are encouraged to expand their offering into the rest of the world.

\section{Conclusion}

Coaching in Africa started later than in the United States of America and Europe. Given its relatively small size compared with the global market, research on African coaching is often grouped together with other regions, obscuring its unique context-specific aspects. To the best of our knowledge, this is the first Pan-African coaching praxis study. The findings shed light on hitherto unknown facets of African coaching practice and provide a set of internationally comparable, actionable guidelines to coaches, coaching training providers and purchasers of coaching services in Africa.

\section{Acknowledgements Competing interests}

The authors declare that they have no financial or personal relationship that may have inappropriately influenced them in writing this article.

\section{Authors' contributions}

N.T. conducted the research and wrote the article. J.P. assisted with the research and reviewed the article. J.M. assisted with the research and reviewed the article.

\section{Funding information}

This research received no specific grant from any funding agency in the public, commercial or not-for-profit sectors.

\section{Data availability}

The authors confirm that the data supporting the findings of this study are available within the article.

\section{Disclaimer}

The views and opinions expressed in this article are those of the authors and do not necessarily reflect the official policy or position of any affiliated agency of the authors.

\section{References}

Angulo, P., Passmore, J., \& Brown, H. (2019). Distinctions in coaching practice between the Island of Ireland and the rest of Europe. The Coaching Psychologist, 15(1).

Athanasopoulou, A., \& Dopson, S. (2018). A systematic review of executive coaching outcomes: Is it the journey or the destination that matters the most? The Leadership Quarterly, 29(1), 70-88. https://doi.org/10.1016/j.leaqua.2017.11.004

Bachkirova, T., Cox, E., \& Clutterbuck, D. (2014). Introduction. In E. Cox, T. Bachkirova, \& D. Clutterbuck (Eds.), The complete handbook of coaching (2nd edn., pp. 1-20). London: Sage.

Blackman, A., Moscardo, G., \& Gray, D.E. (2016). Challenges for the theory and practice of business coaching: A systematic review of empirical evidence. Human Resource Development Review, 15(4), 459-486. https://doi.org/10.1177/1534484316673177

Bono, J.E., Purvanova, R.K., Towler, A.J., \& Peterson, D.B. (2009). A survey of executive coaching practices. Personnel Psychology, 62(2), 361-404. https://doi. org/10.1111/j.1744-6570.2009.01142.x

Bozer, G., \& Jones, R.J. (2018). Understanding the factors that determine workplace coaching effectiveness: A systematic literature review. European Journal of Work and Organizational Psychology, 27(3), 342-361. https://doi.org/10.1080/135943 2X.2018.1446946

Cavett, B.E. (2015). Book review of: Success as a coach: Start and build a successful coaching business. International Journal of Evidence Based Coaching and Mentoring, 13(1), 121-123.

Coutu, D., Kauffman, C., Charan, R., Peterson, D.B., Maccoby, M., \& Scoular, P.A. (2009). What can coaches do for you? Harvard Business Review, 87(1), 91-97.

Cox, E., Bachkirova, T., \& Clutterbuck, D. (2014). Theoretical traditions and coaching genres: Mapping the territory. Advances in Developing Human Resources, 16(2), 139-160. https://doi.org/10.1177/1523422313520194

De Haan, E., Bertie, C., Day, A., \& Sills, C. (2010). Clients' critical moments of coaching: Toward a 'client model' of executive coaching. Academy of Management Learning \& Education, 9, 607-621. https://doi.org/10.5465/amle.2010.56659879

Dunlop, C.W. (2017). The success and failure of the coaching industry. Retrieved from https://www.forbes.com/sites/forbescoachescouncil/2017/10/05/the-successand-failure-of-the-coaching-industry/\#3239dbdb6765

Grant, A.M. (2012). Making positive change: A randomized study comparing solutionfocused vs. problem-focused coaching questions. Journal of Systemic Therapies, 31(2), 21-35. https://doi.org/10.1521/jsyt.2012.31.2.21

Grant, A.M., Cavanagh, M.J., \& Parker, H.M. (2010). The state of play in coaching today: A comprehensive review of the field. International Review of Industrial and Organizational Psychology, 25, 125-167. https://doi.org/10.1002/97804 70661628.ch4

Hawkins, P., Turner, E., \& Passmore, J. (2019). The manifesto for supervision. Henleyon-Thames: Henley Business School. 
International Coach Federation (ICF). (2020a). 2020 ICF global coaching study: Executive summary. Retrieved from https://coachfederation.org/app/ Executive summary. Retrieved from https://coachfeder
uploads/2020/09/FINAL_ICF_GCS2020_ExecutiveSummary.pdf

International Coach Federation (ICF). (2020b). Membership and credentialing fact sheet August 2020. Retrieved from https://coachfederation.org/app/ uploads/2020/08/August2020_FactSheet.pdf

Kombarakaran, F.A., Yang, J.A., Baker, M.N., \& Fernandes, P.B. (2008). Executive coaching: It works! Consulting Psychology Journal: Practice and Research, 60(1), 78-90. https://doi.org/10.1037/1065-9293.60.1.78

Maltbia, T.E., Marsick, V.J., \& Ghosh, R. (2014). Executive and organizational coaching. Advances in Developing Human Resources, 16(2), 161-183. https://dol. org/10.1177/1523422313520474

Passmore, J. (Ed.). (2015). Excellence in coaching: The industry guide. London: Kogan Page.

Passmore, J., Brown, H., Csigas, Z., \& the European Coaching and Mentoring Research Consortium. (2017). Executive report 2017: The state of play in European coaching \& mentoring. Henley-on-Thames: Henley Business School and EMCC International. Retrieved from https://assets.henley.ac.uk/defaultUploads/The-State-of-Playin-European-Coaching-Mentoring-Executive-Report-2017.pdf? mtime= 20171204192802

Passmore, J., \& Dromantaite, A. (2020). Coaching in Baltic States (Lithuania, Latvia \& Estonia): A European survey. Management Theory and Studies for Rural Business and Infrastructure Development, 41(4), 561-575. https://doi.org/10.15544/ mts.2019.46

Passmore, J., \& Fillery-Travis, A. (2011). A critical review of executive coaching research: A decade of progress and what's to come. Coaching: An International Journal of Theory, Research and Practice, 4(2), 70-88. https://doi.org/10.1080/17 521882.2011.596484
Passmore, J., \& Lai, Y.-L. (2019). Coaching psychology: Exploring definitions and research contribution to practice. International Coaching Psychology Review, 14(2) 69-83. Retrieved from https://eprints.bbk.ac.uk/id/eprint/31999/

Schutte, F. (2019). Business coaching: A hen with ducklings. South African Journal of Business Management, 50(1), a398. https://doi.org/10.4102/sajbm.v50i1.398

Sherman, S., \& Freas, A. (2004). The wild west of executive coaching. Harvard Business Review, 82(11), 82-93. Retrieved from https://hbr.org/2004/11/the-wild-west-ofexecutive-coaching

Sherpa Coaching. (2020). Executive coaching survey summary. Retrieved from https:// www.sherpacoaching.com/pdf_files/2020_Executive_Coaching_Survey EXECUTIVE_SUMMARY_FINAL.pdf

Stern, L.R. (2004). Executive coaching: A working definition. Consulting Psychology Journal: Practice and Research, 56(3), 154-162. https://doi.org/10.1037/10659293.56.3.154

Stout-Rostron, S. (2006). The history of coaching. In M. McLoughlin (Ed.), Sharing the passion: Conversations with coaches, pp. 16-41. Cape Town: Advanced Human Technologies.

Stout-Rostron, S., \& Van Rensburg, M.J. (2009). Business coaching: Wisdom and practice: Unlocking the secrets of business coaching. Randburg: Knowledge Resources.

Terblanche, N.H.D., Jock, R.J., \& Ungerer, M. (2019). Creating and maintaining a commercially viable executive coaching practice in South Africa. Southern African Journal of Entrepreneurship and Small Business Management, 11(1), a192. https://doi.org/10.4102/sajesbm.v11i1.192

Theeboom, T., Beersma, B., \& Van Vianen, A.E. (2014). Does coaching work? A metaanalysis on the effects of coaching on individual level outcomes in an organizational context. The Journal of Positive Psychology, 9(1), 1-18. https://doi.org/10.1080/1 7439760.2013 .837499 